\title{
Laparoscopic subtotal gastrectomy with Roux-en-Y reconstruction for long-term anticoagulation in gastric antral vascular ectasia syndrome
}

\author{
Derek Lim, ${ }^{1}$ Shinban Liu, ${ }^{0}$ Vadim Meytes, ${ }^{2}$ Brian Binetti ${ }^{2}$
}

${ }^{1}$ General Surgery, NYU Langone Medical Center, Brooklyn, New York, USA

${ }^{2}$ General Surgery, Health Quest Medical Practice, Poughkeepsie, New York, USA

\section{Correspondence to Dr Shinban Liu, \\ shinban.liu@nyumc.org}

DL and SL contributed equally.

Accepted 15 May 2019

\section{DESCRIPTION}

A 56-year-old woman with gastric antral vascular ectasia (GAVE) syndrome as diagnosed on endoscopy (figure 1) had an extensive history of recurrent gastric bleeding that required multiple endoscopic interventions, transfusions and hospitalisations. While her previous episodes had always been successfully managed with endoscopic epinephrine injections and electrocautery, she had recently been diagnosed with deep vein thromboses and a pulmonary embolus requiring long-term anticoagulation. After an extensive discussion with her gastroenterologist and haematologist, she underwent a laparoscopic subtotal gastrectomy with Roux-en-Y reconstruction. The patient tolerated the procedure well, and her postoperative course was uncomplicated. Surgical pathology was consistent with GAVE syndrome, which demonstrated hyperplastic mucosa of the antrum, hypertrophy of the lamina propria and vascular ectasia.

GAVE is a rare disease that is also known as 'watermelon stomach' due to the characteristic endoscopic appearance of parallel red stripes of tortuous ectatic vessels along the antral mucosal folds. The aetiology of GAVE syndrome is largely unknown but is often associated with comorbidities such as liver cirrhosis, connective tissue diseases, Raynaud's disease and chronic kidney disease. ${ }^{12}$ It is more common in women, and endoscopy is the gold standard for the diagnosis and treatment of GAVE syndrome. This rare disease accounts for roughly $4 \%$ of nonvariceal upper gastrointestinal bleeding, which may lead to chronic blood loss and iron-deficiency anaemia. ${ }^{12}$ As a result, approximately $62 \%$ of these patients become transfusion dependent. ${ }^{2}$ GAVE syndrome is commonly mistaken for gastritis but can be histologically characterised by vascular ectasia of the mucosal capillaries, focal thrombosis and spindle cell proliferation within the lamina propria. $^{23}$

Treatment of GAVE varies from medical management to endoscopic intervention and surgical resection. Conservative management includes steroids, hormone therapy, octreotide, tranexamic acid and thalidomide used to augment endothelium integrity, vascular sensitivity, inhibit angiogenesis and decrease transfusion requirements. Endoscopic management includes cryotherapy, neodymium-yttrium-aluminium garnet laser coagulation, argon plasma coagulation, band ligation or radiofrequency ablation. Surgical treatment is typically reserved for extenuating circumstances and includes gastric antrectomy followed by a Billroth II or Roux-en-Y reconstruction. This has been associated with high success rates with long-term haemostasis and no transfusion requirements in a study with 2-year follow-up. ${ }^{3}$

While a significant amount of research remains to fully understand GAVE syndrome and its optimal management, surgical resection with subsequent reconstruction may prove to be a viable option in select patient populations with severe recurrent bleeding, failure of medical management or necessity of anticoagulation such as the patient described.
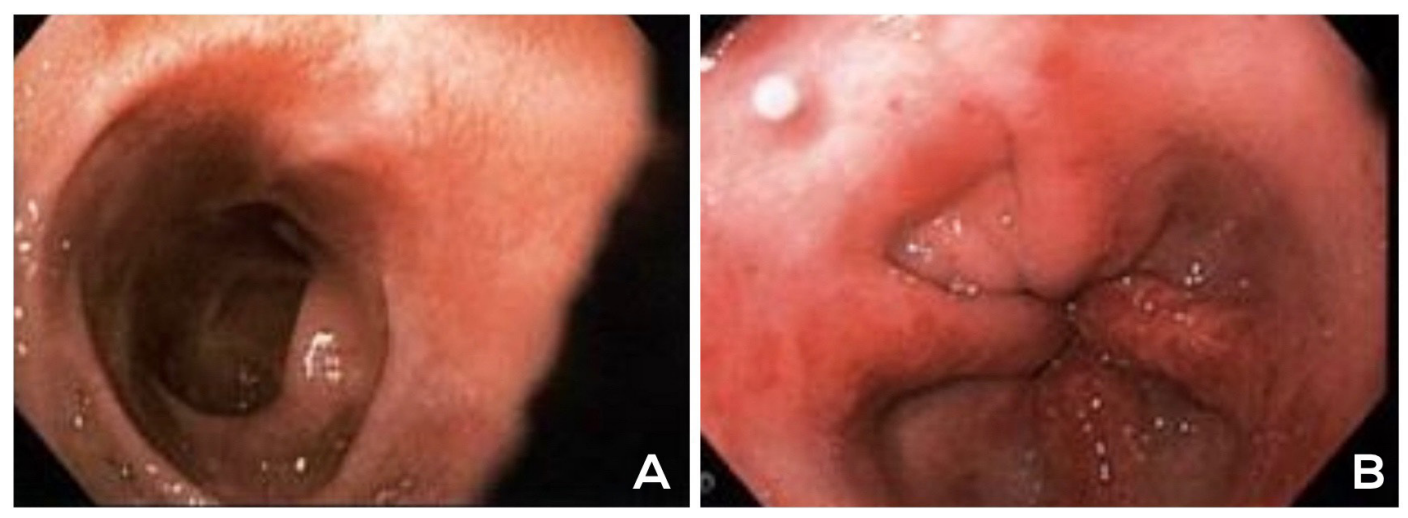

Figure 1 Endoscopic image of the gastric antrum (A) and pylorus (B) demonstrating characteristic red and white stripes secondary to vascular ectasia along hyperplastic mucosal folds. 


\section{Learning points}

- Gastric antral vascular ectasia (GAVE) accounts for only $4 \%$ of non-variceal upper gastrointestinal bleeds, causing patients to become anaemic and often transfusion dependent.

- Endoscopy is the gold standard in diagnosing and treating GAVE syndrome, which reveals characteristic red stripes of vascular ectasia along the gastric antral folds creating a watermelon-like pattern.

- Surgical management is typically reserved for failure of medical and endoscopic management and is associated with high success rates of haemostasis and decreased transfusion dependency.
Contributors DL, SL, VM and BB contributed equally to the drafting, revision and finalisation of this manuscript.

Funding The authors have not declared a specific grant for this research from any funding agency in the public, commercial or not-for-profit sectors.

Competing interests None declared.

Patient consent for publication Obtained.

Provenance and peer review Not commissioned; externally peer reviewed.

\section{REFERENCES}

1 Alkhormi AM, Memon MY, Alqarawi A. Gastric Antral Vascular Ectasia: A Case Report and Literature Review. J Transl Int Med 2018;6:47-51.

2 Fuccio L, Mussetto A, Laterza L, et al. Diagnosis and management of gastric antral vascular ectasia. World J Gastrointest Endosc 2013;5:6-13.

3 Hsu WH, Wang YK, Hsieh MS, et al. Insights into the management of gastric antral vascular ectasia (watermelon stomach). Therap Adv Gastroenterol 2018;11:1756283X1774747.

Copyright 2019 BMJ Publishing Group. All rights reserved. For permission to reuse any of this content visit

https://www.bmj.com/company/products-services/rights-and-licensing/permissions/

BMJ Case Report Fellows may re-use this article for personal use and teaching without any further permission.

Become a Fellow of BMJ Case Reports today and you can:

- Submit as many cases as you like

- Enjoy fast sympathetic peer review and rapid publication of accepted articles

- Access all the published articles

Re-use any of the published material for personal use and teaching without further permission

Customer Service

If you have any further queries about your subscription, please contact our customer services team on +44 (0) 2071111105 or via email at support@bmj.com.

Visit casereports.bmj.com for more articles like this and to become a Fellow 